\title{
SYNTHESIS, CHARACTERIZATION AND ANTIMICROBIAL ACTIVITY OF SOME TRANSITION METALS COMPLEXES DERIVED FROM BIS- PYRAZOLINE BASED LIGAND
}

\author{
Abdu-Rahman M.Fahad ${ }^{1 \mathrm{a}}$ and Mahmoud Najim Abid ${ }^{2 a^{*}}$ \\ aDepartment of Chemistry, College of Science, Mustansiriyah University, Baghdad, IRAQ. \\ Email: abdonn919@yahoo.com ${ }^{1}$; Mahmoud_inor71@uomustansiriyah.edu.iq ${ }^{2}$ \\ *Corresponding author: mahmoudaljibouri@gmail.com \\ Received: $20^{\text {th }}$ May $2019 \quad$ Accepted: $30^{\text {th }}$ Nov 2019 \\ Published: $31^{\text {st }}$ Dec 2019
}

DOI: https://doi.org/10.22452/mjs.vol38no3.6

\begin{abstract}
A series of binuclear transition metal complexes with a general composition of (M2L(H2O)2Cl3, [Zn2LCl3 ) where (M=Mn(II), $\mathrm{Co}(\mathrm{II}), \mathrm{Ni}(\mathrm{II})$ and $\mathrm{Cu}(\mathrm{II}), \mathrm{L}=.5,5$ '-(5-(tertbutyl)-2-hydroxy-1,3-phenylene)bis(3-methyl-4,5-dihydro-1H-pyrazole-1-carbothioamide) are reported herein. The new pyrazoline ligand was synthesized via the ring closure of 4,4'-(5-(tertbutyl)-2-hydroxy-1,3-phenylene)bis(but-3-en-2-one) in an alkaline solution of thiosemicarbazide after adjusting the stoichiometric ratios of the reactants. The new bis-2-pyrazoline was fully characterized by EIMS, NMR, FT-IR and elemental analyses upon completion of the TLC technique. The metal complexes of the new ligand were isolated in their solid state after adjusting the mole ratios (M:HL) 2:1 through the reaction of the metal chlorides with the ethanolic solution of the ligand (HL). The metal complexes were fully characterized by elemental analysis, molar conductance, molecular weight determination, FT-IR, UV-Visible and magnetic measurements. Molecular weight determination of these complexes indicate a binuclear nature. The octahedral geometry was confirmed on the basics of electronic spectra and magnetic measurement together with spectral and flame atomic absorption data. The zinc (II) complex was tetrahedral geometry with the formula $\mathrm{Zn}_{2} \mathrm{LCl}_{3}$. The complexes are non-electrolytic in nature negligible molar conductance. The anti-microbial activities of these derivatives have been studied by screening them against bacteria such as Staphylococcus aureus and Eschericheia Coli and fungi such as Aspergillus nidulece and Condida albicance by the serial dilution method.
\end{abstract}

Key words: Bis-2-pyrazoline ligands, Binuclear complexes of pyrazoline-based ligands, Biological activity of pyrazole complexes

\section{INTRODUCTION}

The coordination chemistry of bispyrazolederivatives is typically derived from the acyclic binucleating end-off compartment ligands (Chetna, K. Mohammad et al. 2014;Zuhal Ozdemir et al 2008). The binuclear complexes of pyrazole ligands besides being biologically, have considerable analytical, industrial and biochemical importance (Bogumiła, K. et al 2013,Attila, K. et al. 2007).The bidentate pyrazole ligands containing $\mathrm{S}, \mathrm{N}$ and $\mathrm{O}$-donor atoms were reported by many researchers due to the wide applications such as antitumor (Kratz F. etal, 2010), antifungal (Grotjahn D.B. et al, 2003, Sau, D. K. et al 2003), antiviral and insecticides agents (Grotjahn D.B. et al 
2003). The use of transition metal complexes with azo dyes containing strong donor groups have also been used as spray reagent in chromatography.

\section{EXPERIMENTAL}

All reagents and chemicals were commercially available and were used as received from the suppliers. The starting materials; 2,6-diformyl-4-tert-butylphenol, thiosemicarbazide (Merck), acetone $99 \%, \mathrm{P}$ , $\mathrm{CuCl}_{2} .2 \mathrm{H}_{2} \mathrm{O}, \quad \mathrm{ZnCl}_{2}, \quad \mathrm{CoCl}_{2} .6 \mathrm{H}_{2} \mathrm{O}$, $\mathrm{NiCl}_{2} .6 \mathrm{H}_{2} \mathrm{O}$ and $\mathrm{MnCl}_{2} .2 \mathrm{H}_{2} \mathrm{O}$ were supplied from Sigma-Aldrich. All work were conducted in Chemistry Department, College of Science, Mustansiriyah University.

The melting points were determined in open capillaries and were uncorrected. The conductivity of the complexes were measured on Philips digital conductivity meter with dipping- type conductivity cell at $27{ }^{\circ} \mathrm{C}$ in $10^{-3} \mathrm{M}$ solution in DMF. The vibration absorptions spectra were recorded on Shimadzu FT-IR spectrometer. The UVVisible spectra of the ligand and its complexes were measured in the region
(200-800) $\mathrm{nm}$ on Varian Cary 100 Conc. UV-Visible spectrometer. The NMR spectra of chalcone and ligand were measured in d6DMSO solvent on Bruker $400 \mathrm{MHz}$ NMR spectrometer at Faculty of Chemistry, GhaziEntab, University, Turkey. The magnetic moments were measured by Faraday's method on Sherwood magnetic balance at $300{ }^{\circ} \mathrm{K}$ temperature. The metal contents in the solid complexes were estimated by flame atomic absorption spectroscopy (FAAS) via standard methods, Table (1).

\subsection{Synthesis of Chalcone}

(1.65 g, 10 mmoles) of 2,6-diformyl4-tert-butylphenol dissolved in $(20 \mathrm{ml})$ methanol was added gradually to (20 mmoles, $10 \mathrm{ml}$ ) acetone followed by $5 \%$ $\mathrm{NaOH}$ solution. The reaction mixture was stirred at room temperature for three hours. A deep orange precipitate was formed, collected by filtration and were recrystallized using chloroform to give deepyellow crystals of the novel chalcone after keeping the precipitate overnight for 24 hours, Scheme(1).

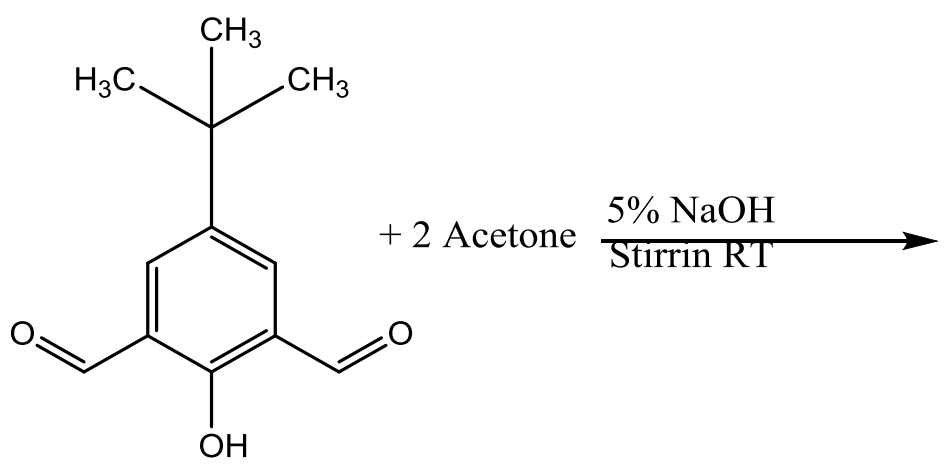<smiles>CC(=O)C=Cc1cc(C(C)(C)C)cc(C=CC(C)=O)c1O</smiles>

Scheme 1. Synthesis of chalcone, (A). 
2.2 Synthesis of 5,5'-(5-(tert-butyl)-2hydroxy-1,3-phenylene)bis(3-methyl-4,5dihydro-1H-pyrazole-1-carbothioamide

$(0.286 \mathrm{~g}, 1 \mathrm{mmole})$ of chalcone A and thiosemicarbazide (1.35 g,2.2 mmoles) in 1:2 molar ratio were mixed in $100 \mathrm{ml}$ of hot methanol. The reaction mixture were refluxed for 30 minutes in a water bath before the $\mathrm{pH}$ of the solution was adjusted to slightly alkaline by using $10 \% \mathrm{NaOH}$ solution $(\mathrm{pH}=8.0)$. The reaction mixture was left to reflux for about 12 hours. The precipitate was filtered off, dried in an oven then recrystallized from hot methanol to afford the yellow crystals of the ligand, Scheme (2).<smiles>CC(=O)C=Cc1cc(C(C)(C)C)cc(C=CC(C)=O)c1O</smiles>

Scheme 2. Synthesis of ligand, HL

\subsection{Synthesis of Metal Complexes}

A mixtures (2 mmoles) of ethonolic solution of metal chlorides $(0.34$ g. $\left.\mathrm{CuCl}_{2} .2 \mathrm{H}_{2} \mathrm{O}\right),\left(0.257 \mathrm{~g}, \quad \mathrm{NiCl}_{2} .6 \mathrm{H}_{2} \mathrm{O}\right)$, $\left(0.44 \mathrm{~g} \quad \mathrm{CoCl}_{2} .6 \mathrm{H}_{2} \mathrm{O}\right), \quad(0.375 \mathrm{gm}$, $\left.\mathrm{MnCl}_{2} .4 \mathrm{H}_{2} \mathrm{O}\right)$ and $\left(0.36 \mathrm{gm}\right.$ of $\left.\mathrm{ZnCl}_{2}\right)$ with (1 mmole, $0.433 \mathrm{~g} \mathrm{gm})$ of ligand dissolved in (15 $\mathrm{ml})$ hot methanol were refluxed for (1-3) hours and few drops of $5 \% \mathrm{NH}_{3}$ solution were added to the reaction mixture and maintain at $\mathrm{pH}$ to $\approx 6-7)$. The precipitate was filtered off, dried in vacuum in a desiccator over anhydrous calcium chloride for three hours, Table (1).

\section{RESULTS AND DISCUSSION}

\subsection{Mass spectra}


nuclear spin of phenolic $-\mathrm{OH}$ and thioamide $-\mathrm{H}_{2} \mathrm{~N}-\mathrm{C}=\mathrm{S}$ protons respectively (Grotjahn D.B. et al. (2003) \& Frankiine K. et al. 2008), in Figure (3). The peaks around (7.78.50) ppm are attributed to the nuclear spin of aromatic Ar-H protons whereas the peaks at 2.6 and $3.70 \mathrm{ppm}$ are assigned to the aliphatic $-\mathrm{CH}_{3}$ of tert-butyl group and vicinal and germinal protons of 2-pyrazoline ring respectively (Maurya et al. 2008). The ${ }^{13} \mathrm{C}$ NMR spectrum of the ligand were recorded in $d_{6}$-DMSO and the peaks observed at 15,18 , 21 and $74.8 \mathrm{ppm}$ are related to the aliphatic $\mathrm{CH}_{3},-\mathrm{C}-\mathrm{CH}_{3},-\mathrm{CH}_{2}-\mathrm{CH}$ - of the 2-pyrazoline ring (Figure 4). The peaks around (160153.2) $\mathrm{ppm}$ are assigned to aromatic carbon atoms and $-\mathrm{C}=\mathrm{N}$ - of pyrazoline ring. The peaks at 188.9 and (169.2-162) ppm are associated with the nuclear spin of $-\mathrm{C}=\mathrm{S}$ and -C-O moiety respectively [M. Goldstein et al. 1970 ; Krishan,C.H. et al. 1977).

\subsection{Infrared Spectra}

The IR spectrum of chalcone (A) in $\mathrm{KBr}$ disc exhibited strong absorption around (1650-1675) $\mathrm{cm}^{-1}$ which is attributed to vibration mode of carbonyl $-\mathrm{C}=\mathrm{O}$ attached to $-\mathrm{C}=\mathrm{C}$ in alpha-beta unsaturated compound (D.L Pavia et al. 2001). The absorptions around (1500-1600), 1275 and $2975 \mathrm{~cm}^{-1}$ are assigned to $-\mathrm{C}=\mathrm{C},-\mathrm{C}-\mathrm{O}$ and $-\mathrm{C}-\mathrm{H}$ respectively (Tang H. et al. 2013). 2pyrazoline ligand displayed new band around 1640, 1570, (3400-3180), 1080 and $1345 \mathrm{~cm}^{-}$ ${ }^{1}$ associated with the $-\mathrm{C}=\mathrm{N}-,-\mathrm{C}=\mathrm{C}-, \mathrm{NH}_{2}$ and $-\mathrm{C}=\mathrm{S}$ groups, respectively, which confirmed the formation of 2-pyrazoline rings of bistype (Julio, P. Lucia, R. 2009). The FT-IR spectra of all complexes showed lower frequencies in the region (1100-1310) $\mathrm{cm}^{-1}$ and (1657-1606) $\mathrm{cm}^{-1}$ of the thioamide and $\mathrm{C}=\mathrm{N}$ - of pyrazoline moiety, therefore is a strong evidence for the participation of the two moiety in binding with the metal ion (Jons, J. et al. 1993). The broad absorptions around (3498-3300) $\mathrm{cm}^{-1}$ revealed the hydrogen bonded $-\mathrm{NH}_{2}$ of the thioamide moiety and coordinated water molecules in the inner-sphere of complexes. The weak bands around (586-534) and (405-432) $\mathrm{cm}^{-1}$ confirmed the formation of $\mathrm{M}-\mathrm{N}$ and $\mathrm{M}-\mathrm{S}$ bonds (Julio, P. Lucia, R (2009) \& Nakamato, K.1997). The medium bands at around (2927-2750) $\mathrm{cm}^{-1}$ region in the complexes reveal that the phenolic $-\mathrm{OH}$ is coordinated to the metal ions, suggesting deprotonation during the formation of M-OM bridge bonds (D.L Pavia et al. 2001). The high intensity bands around (1250-1245) $\mathrm{cm}^{-}$ 1 in the vicinity of (1325-1350) $\mathrm{cm}^{-1}$ are associated with the phenolic $-\mathrm{C}-\mathrm{O}$ bonds.

\subsection{Electronic spectra and magnetic musceptibility measurements}

The electronic spectra of the free ligand, HL and its metal complexes were measured in the range $(10,000-25,000) \mathrm{cm}^{-1}$. The dark brown solution of Mn (II) complex showed high intensity bands at around 28571 and $45455 \mathrm{~cm}^{-1}$ which are associated with the LMCT and ligand transitions, respectively. The weak absorption at $22222 \mathrm{~cm}^{-1}$ is clearly attributed to the ${ }^{6} \mathrm{~A}_{1} \mathrm{~g} \rightarrow{ }^{4} \mathrm{~T}_{1} \mathrm{~g}(\mathrm{~F})$ transition. However the observed magnetic moment of 4.75 BM of the Mn (II) complex was less than expected for an octahedral environment is due to the weak interactions of Mn-O-Mn and Mn-Cl-Mn bridges [Mane et al. 2002]. The cobalt (II) complex -exhibited three bands in the regions (10.000-30.000) $\mathrm{cm}^{-1}$ assigned to the ${ }^{4} \mathrm{~T}_{1} \mathrm{~g}(\mathrm{~F}) \rightarrow{ }^{4} \mathrm{~T}_{2} \mathrm{~g}(\mathrm{~F}),{ }^{4} \mathrm{~T}_{1} \mathrm{~g}(\mathrm{~F}) \rightarrow{ }^{4} \mathrm{~A}_{2} \mathrm{~g}(\mathrm{~F})$ and ${ }^{4} \mathrm{~T}_{1} \mathrm{~g}(\mathrm{~F}) \rightarrow{ }^{4} \mathrm{~T}_{1} \mathrm{~g}(\mathrm{P})$ and confirms the octahedral geometry (Elzbieta, B. et al. 2007). The proposed geometry is further confirmed by the weak anti ferromagnetic behavior in the range of $3.89 \mathrm{~B} . \mathrm{M}$. due to the Co-O-Co and Co-Cl-Co bridges bonds (Lever, A.B. 1994).The electronic spectra of $\mathrm{Ni}$ (II) complex displayed three bands in the 
region of $13.000,19.700$ and $25,300 \mathrm{~cm}^{-1}$ which are assigned to the ${ }^{3} \mathrm{~A}_{2} \mathrm{~g}(\mathrm{~F}) \rightarrow{ }^{3} \mathrm{~T}_{2} \mathrm{~g}(\mathrm{~F}),{ }^{3} \mathrm{~T}_{12} \mathrm{~g}(\mathrm{~F}) \quad$ and $\quad{ }^{3} \mathrm{~T}_{1} \mathrm{~g}(\mathrm{P})$ transitions, respectively, suggesting an octahedral environment around the nickel (II) ion (R.L.Carlin et al. 1997). The magnetic moment of nickel (II) complex is $2.80 \mathrm{BM}$ which is a strong evidence for the octahedral environment around the $\mathrm{Ni}$ (II) ion (Syamal and Maurya, (1986) \& Stapathy et al. 1991). Furthermore, the olive solution of copper (II) complex in DMF showed two bands in the region (13.800- 28.600) $\mathrm{cm}^{-1}$ which are consistent with the ${ }^{2} \mathrm{Eg} \rightarrow{ }^{2} \mathrm{~T}_{2} \mathrm{~g}$ and LMCT transitions, respectively, which confirms the distorted octahedral geometry. Further evidence for the weak anti ferromagnetic properties and metal-phenoxy and metalchloro bridges was investigated from the diamagnetic character of the copper (II) complex which shows zero magnetic susceptibility (Lever, A.B. (1994) \& Satish, M.A. 2007). However the molar conductance values of complexes in DMSO in the range (18-20) ohm-1.cm2.mole-1 indicate the neutral behavior of all complexes (Jerry, W.J. 1994).

\subsection{Antimicrobial Activity}

The obtained inhibition zones $(\mathrm{mm})$ values of the 2-pyrazoline ligand and its metal (II) complexes in $20 \mathrm{ppm}$ concentration are recorded by the diffusion method (Grotjahn D.B. et al. 2003). The activity of the precursor complexes is listed in parenthesis. Like their precursor complexes, the antibacterial activity of the ligand was been tested against two fungi, namely the
Aspergillus nidulence and Candida albicance and two bacteria namely the staphylococcus aureus and Escherichia coli. The values suggest that all the metal complexes were more biologically active compared to the ligands. The observed activities showed that copper (II) complex has the greatest activity compared to the other complexes. The free bis-pyrazoline exhibited low inhibition zones due to the high polarity in DMSO which lessen their ability to cross the lipo layer of the bacteria and fungi cells (Grotjahn D.B. et al. 2003; Frankiine K. et al.2008). The Ciproflaxin was used as standard antibiotic drug as a comparison for the activity of the complexes solutions of 20 ppm.

\section{CONCLUSIONS}

According to the data obtained from the elemental analyses, FT-IR spectra and magnetic moments, the octahedral environment was confirmed around the manganese (II), cobalt (II), nickel (II) and copper (II) ions, whereas, the tetrahedral geometry was proposed for the zinc (II) complex. The binuclear structure was approved via the anti ferromagnetic properties of the complexes at room temperature and the vibration absorptions of the metal-phenoxy-metal data. Furthermore, the results obtained from the IR spectra confirmed that the ligand was coordinated to the metal ions through the nitrogen atom of the pyrazoline ring $-\mathrm{N} 1$, sulfur atom of the thioamide and oxygen of the phenolic $-\mathrm{OH}$, after de-protonation forming a stable fivemembered chelate ring, Scheme(3). 


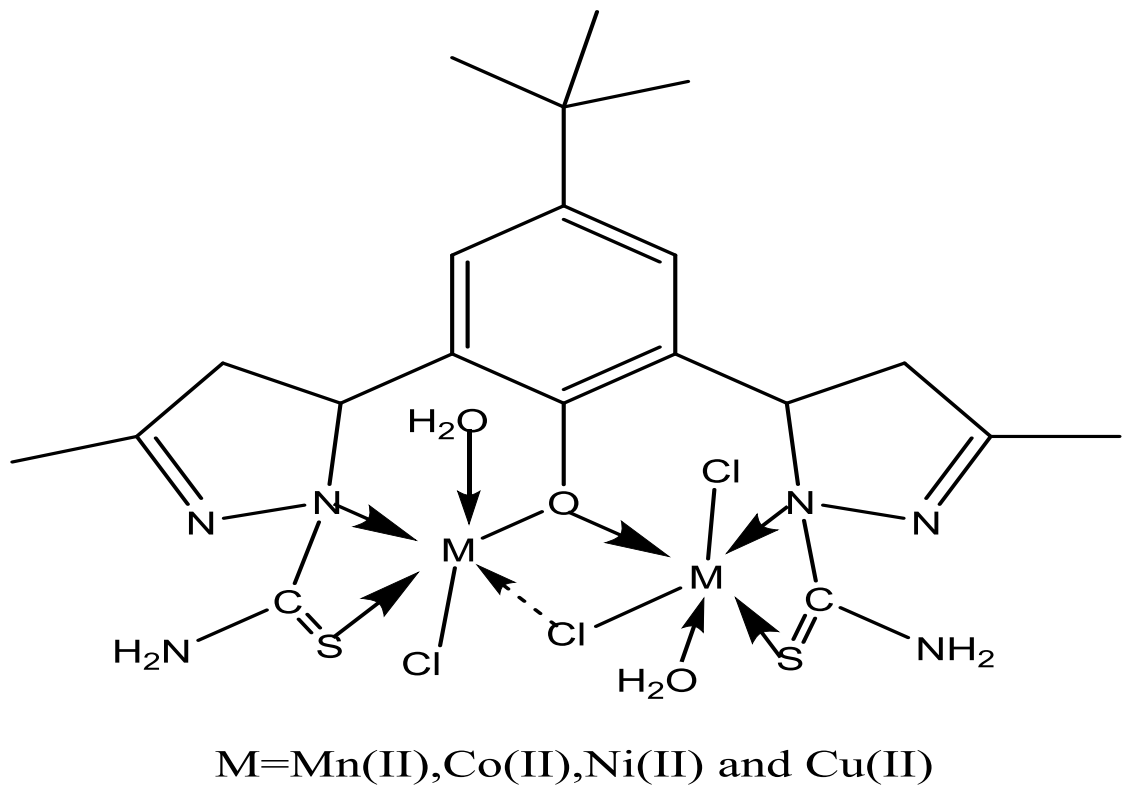

Scheme 3. Octahedral geometry of the prepared $\left[\mathrm{M}_{2} \mathrm{LCl}_{3}\left(\mathrm{H}_{2} \mathrm{O}\right)_{2}\right]$ complexes

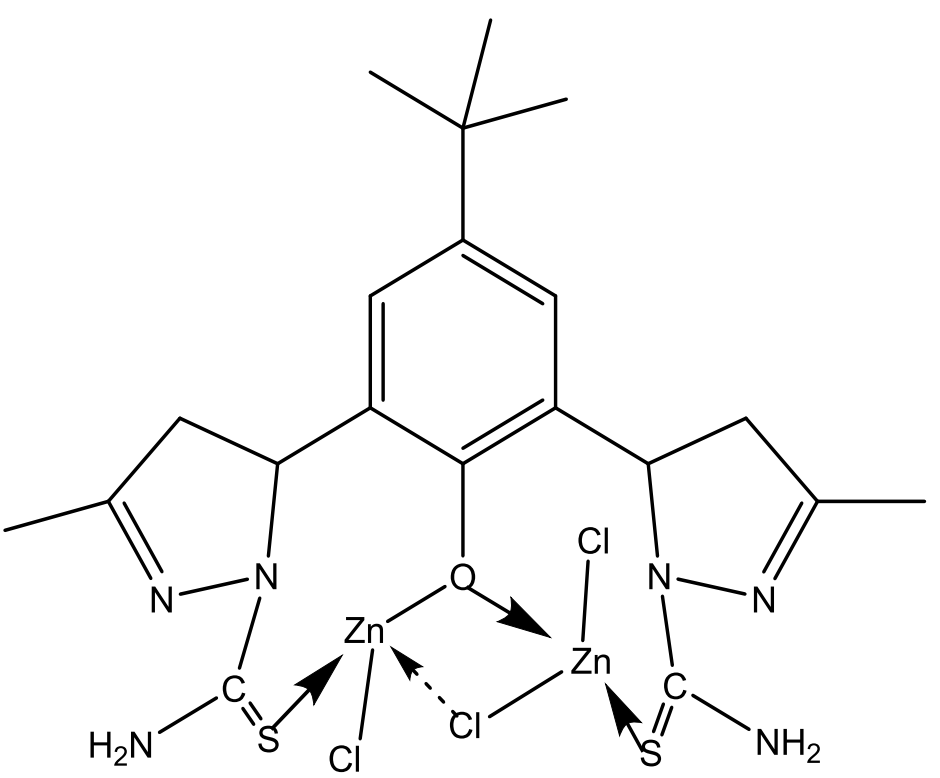

Scheme 4. Tetrahedral geometry of $\left[\mathrm{Zn}_{2} \mathrm{LCl}_{3}\right]$ complex 


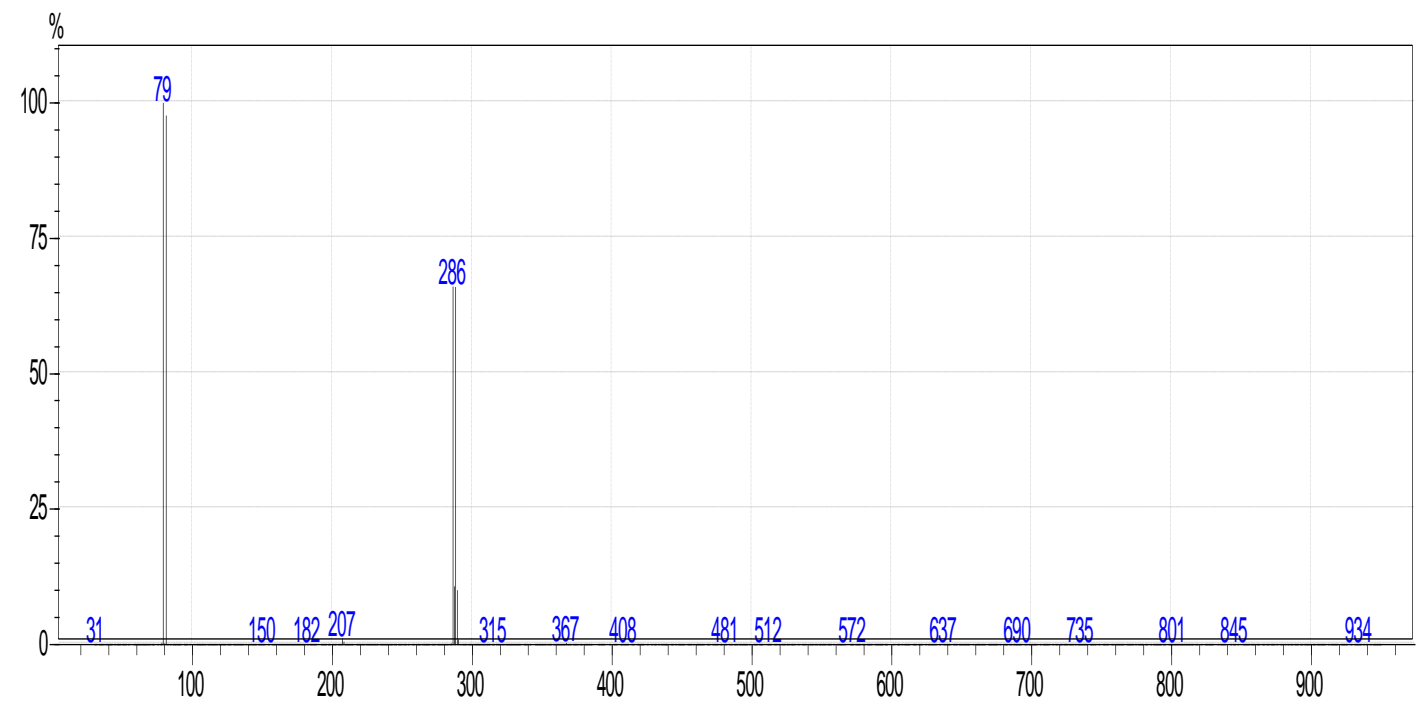

Figure 1. Mass spectrum of chalcone derivative ,A

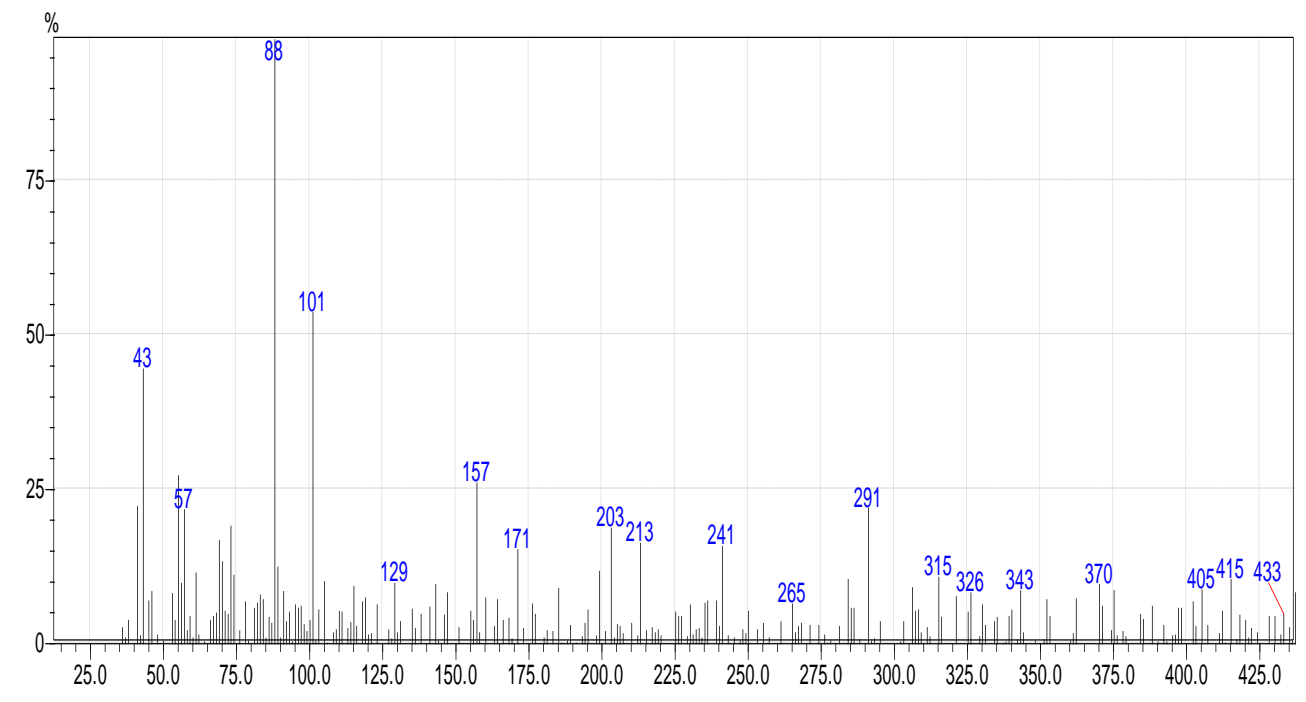

Figure 2. Mass spectrum of ligand, HL 


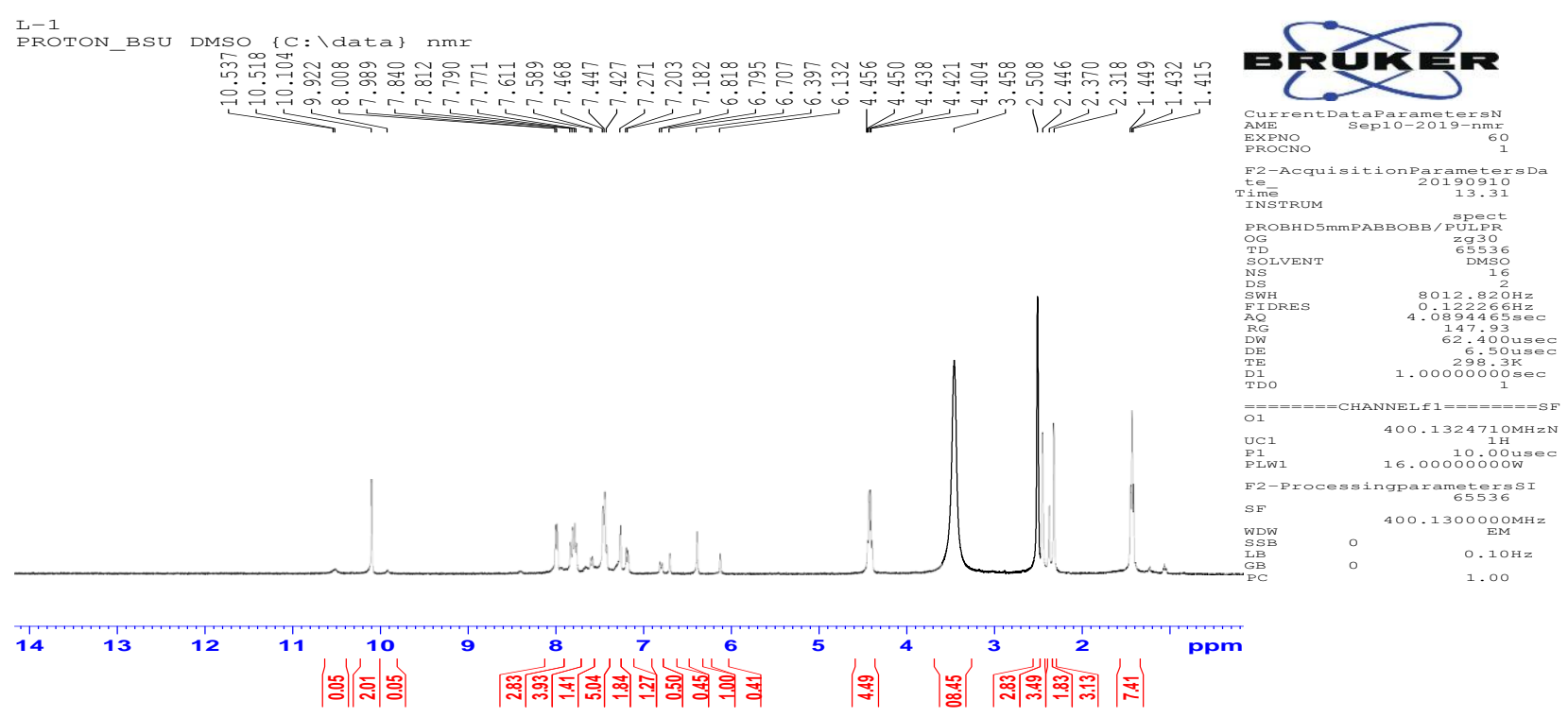

Figure 3. ${ }^{1} \mathrm{H}$ NMR spectrum of HL in DMSO- $d 6$ solvent

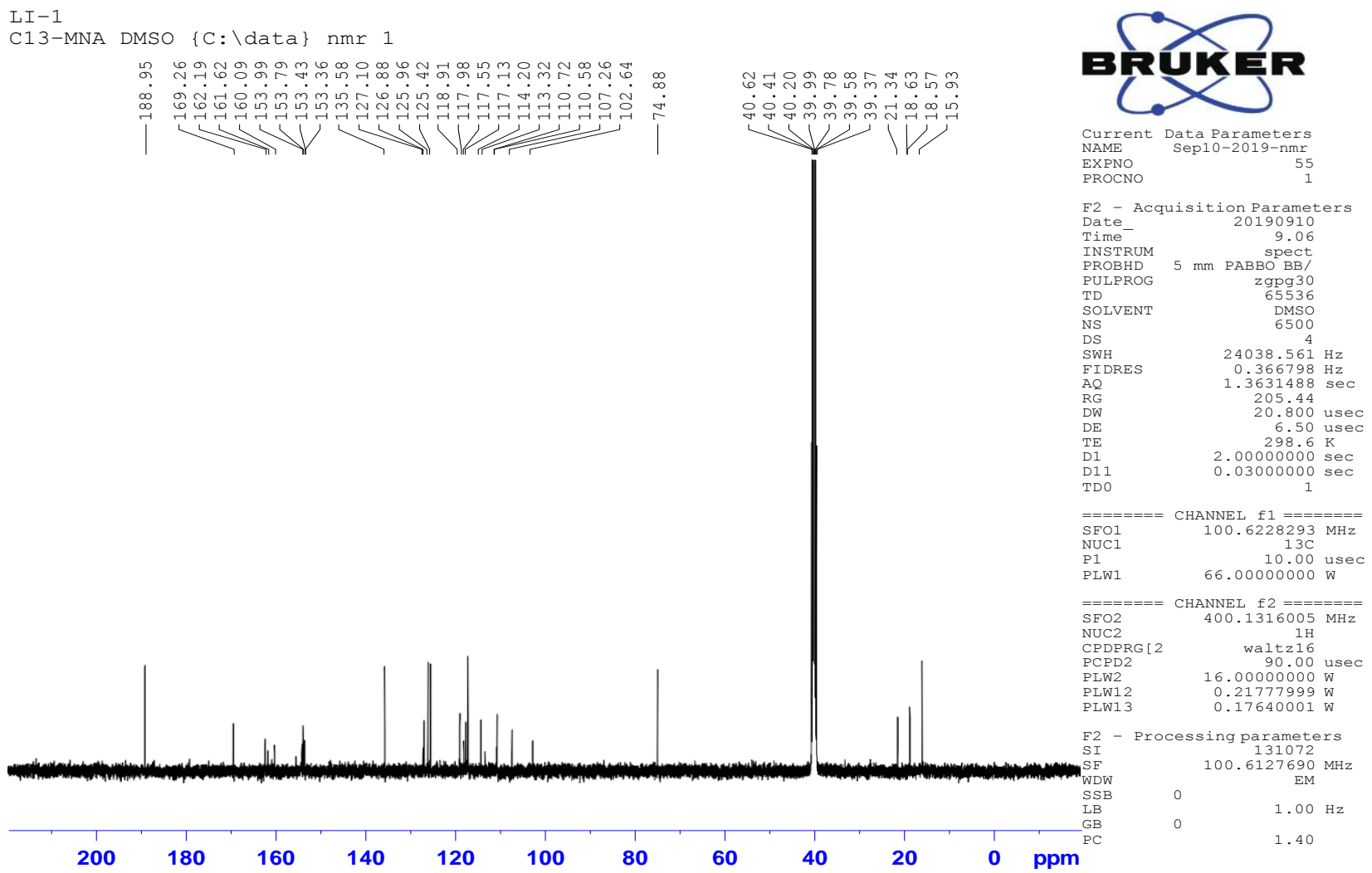

Figure 4. ${ }^{13} \mathrm{C}$ NMR spectrum of HL in DMSO- $d 6$ solvent 
Table 1. Some physical properties and elemental analysis of the prepared complexes

\begin{tabular}{|c|c|c|c|c|c|c|c|}
\hline \multirow[t]{2}{*}{$\begin{array}{l}\text { Compound } \\
\text { Color }\end{array}$} & \multirow[t]{2}{*}{$\begin{array}{c}\Delta \\
\text { S.cm } / \text { mole }\end{array}$} & \multirow[t]{2}{*}{ M.P ${ }^{0} \mathrm{C}$} & \multicolumn{5}{|c|}{$\begin{array}{c}\text { \%Found } \\
\% \text { (Calculated) }\end{array}$} \\
\hline & & & $\mathrm{C}$ & $\mathrm{H}$ & $\mathrm{N}$ & $\mathrm{S}$ & $\mathrm{M}^{\mathrm{a}}$ \\
\hline $\begin{array}{c}{[\mathrm{A}]} \\
\text { Deep yellow }\end{array}$ & & $210-212$ & $\begin{array}{l}74.66 \\
(75.50)\end{array}$ & $\begin{array}{l}6.88 \\
(7.75)\end{array}$ & - & - & - \\
\hline $\begin{array}{l}\text { HL } \\
\text { Yellow }\end{array}$ & & $290-292$ & $\begin{array}{l}54.81 \\
(55.54)\end{array}$ & $\begin{array}{l}5.090 \\
(6.52)\end{array}$ & $\begin{array}{l}19.00 \\
(19.42)\end{array}$ & $\begin{array}{c}14.85 \\
(13.87)\end{array}$ & - \\
\hline $\begin{array}{l}{[\mathrm{MnL}]} \\
\text { Brown }\end{array}$ & 20 & $303 \mathrm{Dec}$ & $\begin{array}{l}36.50 \\
(35.87)\end{array}$ & $\begin{array}{l}4.99 \\
(4.22)\end{array}$ & $\begin{array}{l}12.59 \\
(13.11)\end{array}$ & $\begin{array}{l}8.95 \\
(7.88)\end{array}$ & $\begin{array}{l}16.07 \\
(15.76)\end{array}$ \\
\hline $\begin{array}{l}{[\mathrm{CoL}]} \\
\text { Green }\end{array}$ & 18 & $287 \mathrm{Dec}$ & $\begin{array}{l}35.01 \\
(34.21)\end{array}$ & $\begin{array}{c}4.90 \\
(3.97)\end{array}$ & $\begin{array}{l}12.24 \\
(13.22)\end{array}$ & $\begin{array}{c}9.25 \\
(8.96)\end{array}$ & $\begin{array}{l}17.05 \\
(16.63)\end{array}$ \\
\hline $\begin{array}{l}{[\mathrm{NiL}]} \\
\text { Green }\end{array}$ & 15 & $327 \mathrm{Dec}$ & $\begin{array}{c}32.94 \\
(31.89)\end{array}$ & $\begin{array}{c}4.53 \\
(4.11)\end{array}$ & $\begin{array}{c}11.54 \\
(12.00)\end{array}$ & $\begin{array}{c}8.79 \\
(8.11)\end{array}$ & $\begin{array}{l}16.11 \\
(15.89)\end{array}$ \\
\hline $\begin{array}{l}{[\mathrm{CuL}]} \\
\text { Olive }\end{array}$ & 15 & $283 \mathrm{Dec}$ & $\begin{array}{c}52.80 \\
(52.00)\end{array}$ & $\begin{array}{c}3.11 \\
(2.80)\end{array}$ & $\begin{array}{c}16.44 \\
(17.11)\end{array}$ & $\begin{array}{l}11.08 \\
(11.65)\end{array}$ & $\begin{array}{c}15.78 \\
(16.45)\end{array}$ \\
\hline $\begin{array}{c}{[\mathrm{ZnL}]} \\
\text { Pale yellow }\end{array}$ & 20 & $317 \mathrm{Dec}$ & $\begin{array}{c}35.92 \\
(34.81)\end{array}$ & $\begin{array}{c}4.07 \\
(3.68)\end{array}$ & $\begin{array}{c}12.57 \\
(13.30)\end{array}$ & $\begin{array}{c}9.54 \\
(8.88)\end{array}$ & $\begin{array}{l}19.53 \\
(18.77)\end{array}$ \\
\hline
\end{tabular}


Table 2. I.R. Spectral bands of ligand and their metal complexes

\begin{tabular}{|c|c|c|c|c|c|c|}
\hline Compound & $\mathrm{VC}=0$ & $\mathrm{VC}=\mathrm{N}$ & V-NH & $\begin{array}{l}\mathrm{V}-\mathrm{OH}, \\
-\mathrm{C}-\mathrm{O}\end{array}$ & VM-N & VM-S \\
\hline A & $1650,1675(\mathrm{~s})$ & & $3180(\mathrm{~m})$ & $3450(\mathrm{br})$ & & \\
\hline HL & - & $1640(\mathrm{~s})$ & - & $\begin{array}{c}3400(\mathrm{~m}) \\
1250(\mathrm{~s})\end{array}$ & - & - \\
\hline$[\mathrm{MnL}]$ & - & $1625(\mathrm{~s})$ & $3100(\mathrm{~m})$ & $\begin{array}{c}3550(\mathrm{~m}) \\
1117(\mathrm{~s})\end{array}$ & $515(\mathrm{~m})$ & $400(\mathrm{~m})$ \\
\hline$[\mathrm{CoL}]$ & - & $1635(\mathrm{~s})$ & $3110(\mathrm{~m})$ & $\begin{array}{c}3555(\mathrm{~m}) \\
1271(\mathrm{~s})\end{array}$ & $490(\mathrm{~m})$ & $390(\mathrm{~m})$ \\
\hline [NiL] & - & 1657(s) & $3390(\mathrm{br})$ & $\begin{array}{l}\text { 3598(br), } \\
1277 \text { (sh) }\end{array}$ & $586(w)$ & $405(w)$ \\
\hline [CuL] & - & 1633(s) & 3175 (br) & $\begin{array}{c}3540(\mathrm{br}) \\
1266(\mathrm{~s})\end{array}$ & $545(\mathrm{~m})$ & $435(w)$ \\
\hline$[\mathrm{ZnL}]$ & - & $1662(\mathrm{~s})$ & $3228(\mathrm{~m})$ & $\begin{array}{c}\text { 3431(m) } \\
1269(\mathrm{~s})\end{array}$ & $503(w)$ & $405(w)$ \\
\hline
\end{tabular}

br=broad, $\mathrm{m}=$ medium, $\mathrm{s}=$ strong and $\mathrm{sh}=$ shoulder

Table 3. Wave length, Magnetic Susceptibility and molar extinction coefficient for DMF solution of solid complexes

\begin{tabular}{|c|c|c|c|c|c|}
\hline Compounds & $\begin{array}{l}\text { Molar } \\
\text { Conc. }\end{array}$ & $\mathrm{nm} \lambda$ & $\begin{array}{c}\varepsilon_{0} \mathrm{~L} \mathrm{cmol}^{-1} \\
\mathrm{~cm}^{-1}\end{array}$ & Assignment & $\mu_{\text {eff }}$ \\
\hline [HL] & $1 \times 10^{-3}$ & $\begin{array}{l}225 \\
315\end{array}$ & $\begin{array}{l}28900 \\
30700\end{array}$ & $\begin{array}{l}\pi \rightarrow \pi^{*} \\
\text { INCT }\end{array}$ & - \\
\hline [MnL] & $1 \times 10^{-3}$ & $\begin{array}{l}399 \\
283 \\
240\end{array}$ & $\begin{array}{l}1500 \\
1.640 \\
3.467\end{array}$ & $\begin{array}{c}{ }^{6} \mathrm{~A}_{1} \mathrm{~g} \underset{\mathrm{MLCT}^{4} \mathrm{~T}_{1} \mathrm{~g}(\mathrm{~F})}{\pi \rightarrow \pi^{*}} \\
\pi\end{array}$ & 4.75 \\
\hline$[\mathrm{CoL}]$ & $1 \times 10^{-3}$ & $\begin{array}{l}690 \\
570 \\
395 \\
270\end{array}$ & $\begin{array}{c}1600 \\
700 \\
1080 \\
12700\end{array}$ & $\begin{array}{c}{ }^{4} \mathrm{~T}_{1} \mathrm{~g}_{(\mathrm{F})} \rightarrow{ }^{4} \mathrm{~T}_{2} \mathrm{~g}_{(\mathrm{F})} \\
{ }^{4} \mathrm{~T}_{1} \mathrm{~g}_{(\mathrm{F})} \rightarrow{ }^{4} \mathrm{~A}_{2} \mathrm{~g}_{(\mathrm{F})} \\
{ }^{4} \mathrm{~T}_{1} \mathrm{~g}_{(\mathrm{F})} \rightarrow{ }^{4} \mathrm{~T}_{1} \mathrm{~g}_{(\mathrm{P})} \\
\mathrm{LMCT} \\
\pi \rightarrow \pi^{*}\end{array}$ & 3.89 \\
\hline
\end{tabular}




\begin{tabular}{|c|c|c|c|c|c|}
\hline$[\mathrm{NiL}]$ & $1 \times 10^{-4}$ & $\begin{array}{l}750 \\
550 \\
450\end{array}$ & $\begin{array}{c}555 \\
1200 \\
9040\end{array}$ & $\begin{array}{l}{ }^{3} \mathrm{~A}_{2} \mathrm{~g} \rightarrow{ }^{3} \mathrm{~T}_{2} \mathrm{~g} \\
{ }^{3} \mathrm{~A}_{2} \mathrm{~g} \rightarrow{ }^{3} \mathrm{~T}_{1} \mathrm{~g} \\
{ }^{3} \mathrm{~A}_{2} \mathrm{~g} \rightarrow{ }^{3} \mathrm{~T}_{1} \mathrm{~g}^{(\mathrm{P})}\end{array}$ & 2.80 \\
\hline$[\mathrm{CuL}]$ & $1 \times 10^{-4}$ & $\begin{array}{l}830 \\
309 \\
287\end{array}$ & $\begin{array}{c}120 \\
75 \\
2700\end{array}$ & $\begin{array}{c}{ }^{2} \mathrm{~B}_{1} \mathrm{~g} \rightarrow{ }^{2} \mathrm{~B}_{2} \mathrm{~g} \\
\mathrm{LMCT} \\
\pi \rightarrow \pi^{*}\end{array}$ & 0.0 \\
\hline$[\mathrm{ZnL}]$ & $1 \times 10^{-4}$ & $\begin{array}{l}370 \\
210\end{array}$ & $\begin{array}{l}10500 \\
18950\end{array}$ & $\begin{array}{l}\text { MLCT } \\
\pi \rightarrow \pi^{*}\end{array}$ & 0.00 \\
\hline
\end{tabular}

LMCT and MLCT=Ligand to metal charge transfer or vice-versa

Table 4. Inhibition zones ( $\mathrm{mm}$ ) of HL and its complexes via diffusion method

\section{Compound}

Bacteria

Fungi

\begin{tabular}{ccccc} 
& S.aureus & E.coli & A.nidulence & C.albicance \\
\hline HL & 12 & 20 & 10 & 11 \\
{$[\mathrm{MnL}]$} & 15 & 27 & 13 & 14 \\
{$[\mathrm{CoL}]$} & 22 & 21 & 16 & 18 \\
{$[\mathrm{NiL}]$} & 20 & 22 & 18 & 15 \\
{$[\mathrm{CuL}]$} & 28 & 30 & 20 & 22 \\
{$[\mathrm{ZnL}]$} & 22 & 28 & 15 & 20 \\
Ciproflaxin $(20 \mathrm{ppm})$ & 25 & 15 & 0 & 0 \\
\hline
\end{tabular}

\section{ACKNOWLEDGEMENTS}

We would like to thank to members of service laboratory of chemistry department, college of science, Mustansiriyah university for measuring mass spectra, FT-IR, UV-Visible spectra and magnetic susceptibility of solid complexes.
As well as, authors are so grateful for chemistry department, Ibn-Haitham college of education for pure sciences, Baghdad university for carrying out elemental analyses of chlacone and ligand. 


\section{REFERENCES}

Attila, K., Katalin M.,Vukadin M.,Zoran D. \& Gyorgy, P. (2007). J. OrganoMetalic Chemistry 692m: 2582-2592.

Bogumiła, K., Krzysztof S., Katarzyna M., KamilaK., Malgorzata C., Bernhard K. \& El-Zbieta B. (2013). Copper(II) complexes with derivatives of pyrazole as potential antioxidant enzyme mimics Med. Chem. Research 22:2395-2402.

Casas J.S., Castellano E.E., Ellena J., GarcıTasende M.S., Luz Perez-Paralle M., Sanchez A., Sanchez-Gonzalez, A., Sordo, J.\& Touceda A. (2008). New $\mathrm{Pd}(\mathrm{II})$ and $\mathrm{Pt}(\mathrm{II})$ complexes with $\mathrm{N}$, Schelated pyrazolonate ligands: molecular and supramolecular structure and preliminary study of their in vitro antitumoral activity. J. Inorg. Biochem. 102 (1), 33-45.

Carlin , R.L. Vandryneveledt, A.J. (1997),. Magnetic properties of Transition Metal compounds Springer-verlag, New York PP.1-22.

D.L Pavia, D.L.Lampman, G.M., \&G.S.Kriz.(2001). Introduction to Spectroscopy ( $3^{\text {rd }}$ ed.).USA: Books/Cole Thomson Learning: pp.310-315.

Elzbieta, B. Magdalena, M. Bernhard, K. Keppler, Vladimir B., Arion, Grzegorz A. Julio, P. Lucia, R. (2009). Pyrazole Complexes and Supramolecular Chemistry. Eur.J.Inorg.Chem. 33:4913-4925.

Jerry W.J. (1971), Molar Conductivity measurements of Coordination Compounds in organic
solvents,Coord.Chem.Reviews, 7,81122.

Krishan C.H., Mahapatra C.M.\& Dash J.K. (1977). Synthesis and Spectroscopic Novel Transition Metals Complexes with Poly dentate 2-Pyrazoline Ligands. Inorg.Nucl. Chemistry 39:1253-1260.

Lever, A.B.P. (1994). Inorganic Electronic Spectroscopy, Elsevier Science Publisher Amsterdam, 155-160.

K.Nakamoto (1997), Spectroscopy and Structure of Metal Chelate Compounds, John Willey,New York pp.220-228.

Silverstein, R.M. (2003). Spectrometric Identification of Organic compound, $5^{\text {th }}$ Edn. John Wiley, 123-127.

Rossi G.,Rheingold A., Rideout M., Meyer C., Hemande Z.G. \& Mejorado L. (2003). Bimetallic reactivity. Synthesis of bimetallic complexes containing a bis(phosphino)pyrazole ligand. J.Inorg.Chem.42:3347-3355.

Saleem K., Wani W.A., Haque A., Lone M.N. Hsieh M.F., Jairajpuri M.A.\& Ali I., (2013). Synthesis, DNA binding, hemolysis assays and anticancer studies of copper(II), nickel(II) and iron(III) complexes of a pyrazoline-based ligand. Future Med. Chem. 5 (2), 135-146.

Sau D., Butcher K., Chudhuri R.J. \& Saha, S. (2003). Antimicrobial activity of a series of thiosemicarbazones and their $\mathrm{Zn}^{\mathrm{II}}$ and $\mathrm{Pd}^{\mathrm{II}}$ complexes. Mol. Cell. Biochem. 253: 21-29.

Saka K., Tomistc Y., Ue T., Goshima K., Ohminat A.\& M. Tsubomura (2002). 
Structural and spectroscopic studies of binuclear $\mathrm{Cu}^{2+}$ and $\mathrm{Co}^{2+}$ complexes with an amide-based naphthalenophane Inorg. Chim. Acta. 297:64-71.

Saugata K., Atanu J,. Kinsuk D., Sangita R., Sudipta C., James A., Arnold L., Rheingold S. \& Kumar K. (2011). Synthesis, crystal structure, spectroscopic and photoluminescence studies of manganese(II), cobalt(II), cadmium(II), zinc(II) and copper(II) complexes with a pyrazole derived Schiff base ligand. Polyhedron 30:2801-2808.

Sayed and N. Saglain, H. Bioorg.(2014). Synthesis and evaluation of pyrazolines bearing benzothiazole as anti-inflammatory agents. Med. Chemistry 23:5804-5812.

Stapathy, K.C. ,Panda, A.K. , Mishra, R. \&Panda, I. (1991). Binuclear metal complexes. Part III. Complexes of 1hydroxy-2, 3-dimethyl-5carboxylato-1,4-diaza-1,3-pentadiene and 1-hydroxy-2,3-dimethyl-4(2'carboxyphenyl)-1,4-diaza-1, 3butadiene with bivalent transition metal ion complexes. Transition Metal Chemistry, 16, 410-412.

Satish, M.A. , Satisha, M.P., Vidyannand, K.R. (2007). Spectroscopic studies of bridged binuclear complexes of $\mathrm{Co}(\mathrm{II}), \mathrm{Ni}(\mathrm{II}), \mathrm{Cu}(\mathrm{II})$ and $\mathrm{Zn}(\mathrm{II})$. Transition Metal Chemistry 32: 8187.

Syamal, A. , Maurya, R. (1986). Synthesis and characterization of nickel(II), cobalt(II), copper(II), manganese(II), zinc(II), zirconium(IV), dioxouranium(VI) and dioxomolybdenum(VI) complexes of a new Schiff base derived from salicylaldehyde and 5methylpyrazole-3-carbohydrazide. Transition Metal Chemistry 11: 172176.

Ting, H.Y.Silva, A.R.Shi \& F.N. (2013). Six new 3d-4f heterometallic coordination polymers constructed from pyrazole-bridged $\mathrm{Cu}^{\mathrm{II}} \mathrm{Ln}^{\mathrm{III}}$ dinuclear units. Dalton Transaction 42:13997-1405.

Urszula K.\&Marek R. (2007). Anion Separation with Metal-Organic Frameworks. Eur. J. Inorg. Chemistry 10:3728-3735.

Zuhal O., H. Burak K., Bulent G.,Unsal C. \& Bilgin A. (2008). Synthesis and Biological Evaluation of a Series of Substituted Pyrazolo[3,4- $d$ ]-1,2,3triazoles and Pyrazolo[3,4$d$ ]oxazoles. Arch. Pharm. Chemistry 341: 701-707. 